\title{
Effect of Service Quality, Product Quality, and Trust In Customer Satisfaction (Case Study at Bank BRI Syariah KCP Kendal)
}

\author{
Heny Yuningrum ${ }^{1}$, Muyassarah ${ }^{2}$, Risma Dewi Astuti 3 \\ 1,2,3Universitas Islam Negeri Walisongo Semarang, Indonesia \\ heny_yuningrum@walisongo.ac.id
}

\begin{abstract}
Purpose - This study aims to determine the effect of service quality, product quality, and trust on customer satisfaction (a case study at Bank BRI Syariah KCP Kendal).

Method - The type of research carried out is a quantitative approach. The study population was all customers at Bank BRI Syariah KCP Kendal using the incidental sampling technique. Data were collected through a questionnaire or questionnaire with a Likert scale. This study uses validity and reliability tests, then classic assumption test, $\mathrm{t}$ test, $\mathrm{F}$ test, determination test and multiple linear regression equation test.

Result - The results of this study are (1) service quality has a positive and significant effect on customer satisfaction (2) product quality has a positive and significant effect on customer satisfaction (3) trust has a positive and significant effect on customer satisfaction (4) service quality, product quality, and Trust together has a positive and significant effect on customer satisfaction.

Implication - The implication is that service delivery and product quality as well as the trust given by the bank will affect customer satisfaction.

Originality - This study shows that these three variables have a significant correlation to customer satisfaction.
\end{abstract}

Keywords: Service Quality, ProductQuality, Trust, Customer Satisfaction. 
Heny Yuningrum, Muyassarah, Risma Dewi Astuti

\section{Introduction}

The Islamic finance industry has experienced very rapid growth (Awwallin 2015). Based on Article 1 paragraph 1 of Law No.21 of 2008 concerning Islamic Banking, it states that Islamic banking is everything that concerns Islamic banks and sharia business units, including institutions, business activities, and methods and processes for carrying out business activities. The development of the Islamic banking system in Indonesia is carried out within the framework of a dual banking system or dual banking system which together with conventional banking serves the needs of the public. The development of Islamic banking in Indonesia is so fast in line with the increasing public need for Islamic banking services.

Based on data from the 2015-2019 Islamic Banking Roadmap, page 23 explains that the quantity and quality of human resources (HR) is inadequate and Information Technology (IT) is not yet able to support product and service development. Efforts to increase the quantity and quality of human resources are aimed at all parties who play an active role in the development and operation of Islamic banking, this will greatly affect the development efforts of other fields such as product and service development and IT development. It is realized that there are challenges in fulfilling Islamic banking HR. Besides required knowledge of banking and finance business, Islamic banking human resources are also required to understand sharia principles. On the other hand,

In the modern banking world, IT is demanded not only as a supporting activity in a financial activity, but must evolve into a business driver. Good IT penetration capabilities have proven to be able to increase competitiveness and profitability for the bank and its customers. Customers benefit from the almost limitless ease of banking operations. Meanwhile, banks are proven to be able to attract customers (customer acquisition) and are able to reduce operational costs and increase fee-based income.

There are still a number of things that are often the main obstacles and problems to IT development in the banking industry. Including sharia 
banking: first, owner and management awareness of the vital role of IT, owners and management are sometimes reluctant to pay attention to IT costs, because they still think that IT is only a support, not the main business. Second, poor planning for current and future IT needs is in accordance with business development plans so that banks often experience problems in IT procurement and implementation. Third, supervision of IT operations, including the availability of reliable IT auditors. As a result of these conditions, currently the IT capabilities of Islamic banking are still below that of largest and medium conventional banks. including comparison with the parent company IT capabilities of each Islamic banking. This, of course, will limit the ability of Islamic banking to innovate products and improve the quality of its services.

Number of Customer Complaints

\begin{tabular}{|c|c|c|}
\hline Year & $\begin{array}{c}\text { Number } \\
\text { of Complaints }\end{array}$ & Period of time \\
\hline 2018 & 36 & January - December \\
\hline 2019 & 52 & January - December \\
\hline
\end{tabular}

Source: Interviews with Customer Service

Based on the table above, it shows that customer complaints from 2018 to 2019 have increased. Other than that based on interviews conducted by researchers with Laila Manna, BRI Syariah KCP Kendal customer and Yasser Rizky Al Fatah Customer Service BRI Syariah KCP Kendal, the researcher found things related to complaints, as mentioned by Laila Manna, a BRI Syariah customer, that the Automated Teller Machine (ATM) often gets errors when it wants to be used and adds an ATM increase policy without notification. Other things that customers complain about are forgetting ATM card passwords, and complaints about blocked ATM cards. In addition, based on the observations of researchers, there are employees who are more concerned with their personal interests than the interests of customers as evidenced by the presence of one of the employees who left the customer to play on his cellphone and intentionally made the customer wait. 
Heny Yuningrum, Muyassarah, Risma Dewi Astuti

Services are very important in the banking sector, especially Islamic banking (Tjiptono 2014). Service is a bank behavior in order to meet the needs and desires of achieving customer satisfaction. Efforts to develop service quality provided by Sharia Banks are not only based on law but must also be market-oriented or the community as users of banking services. Sharia banks in terms of services to the public, the types of products or services offered need to be improved. This is related to the public's expectation that they have a good relationship with a bank that is comfortable and easy to conduct transactions. Service quality can be interpreted as an effort to fulfill the needs and desires of consumers and the accuracy of its delivery in balancing consumer expectations. Service quality can be identified by comparing consumers' perceptions of the real service they receive or get with the real service they expect or want for the service attributes of a company.

Based on previous research conducted by Hermanto on "The Effect of Sharia Bank HR Service Quality on Customer Satisfaction: A Study at BPRS Berkah Ramadhan" shows that the quality of human resources and service quality has an effect on customer satisfaction, but of the seven existing variables consisting of physical variables Not all of them have a significant effect on customer satisfaction, the reliability variable, the responsiveness variable, the assurance variable, and the empathy variable (Hermanto 2013).

Based on research conducted by Heri Setiawan, Maria Magdalena Minarsih, and Aziz Fathoni on "The Effect of Product Quality, Service Quality, and Trust on Customer Satisfaction and Customer Loyalty with Satisfaction as an Intervening Variable (Case Study on Customers of the Rejo Agung Sukses Koperasi, Ngaliyan Branch) results Partial SPSS testing shows that the variables of product quality, service quality, and trust have a positive and significant effect on customer satisfaction at the Rejo Agung Successful Semarang Cooperative (Setiawan, Minarsih, and Fathoni 2016).

Another study conducted by Zainatun Mastura on "The Effect of Service Quality and Trust on Customer Satisfaction (Study at Bank Aceh Syariah Kpo)" shows that the variables of service quality and customer trust together 
Effect of Service Quality, Product Quality, and...

have a significant effect on customer satisfaction. Service quality variable has a significant effect on customer satisfaction. Customer trust variables have a significant effect on customer satisfaction (Mastura 2018).

In addition to good service, quality products also play an important role in customer satisfaction. Products are very important in a company. Because without a product, the company will not be able to do anything in its business. Products are what can be offered, owned, used, or consumed to meet customer needs, which can be in the form of physical objects, services and organizational premises or ideas. Product quality is something that needs to get the main attention of the company / producer, considering that the quality of a product is closely related to consumer satisfaction, which is the goal of the company's marketing activities. Product quality indicates a measure of the product's durability, the reliability of the product, product accuracy, ease of operation, and nurture them and other attributes that are valued. In addition to the quality of the strategy chosen in marketing a product it also has an important role (Muyassarah 2019). For example, such as the strategy implemented by PT. Panin Bank Syariah Malang Branch Office includes several strategies, namely strategies to pick up balls, referrals, build networks, provide excellent service, and provide satisfactory facilities to increase customer trust and satisfaction, so that existing customers will not run away from the bank.

When a customer has received good service from an Islamic bank, the better the level of trust the customer has in the Islamic bank so that the Islamic bank can maintain good relations with its customers. This is explained by Yusrina (2013: 4) who states that if Islamic banks provide poor service to customers, it will have a negative impact on the image of the bank so that the level of customer confidence will decrease (Yusrina 2013).

Bank BRI Syariah is a banking institution that runs its business based on sharia principles. This bank was previously known as Bank Jasa Artha, which was established in 1969, then the bank was taken over by Bank Rakyat Indonesia and became a Sharia Commercial Bank in 2008. In 2009 the sharia business unit of Bank Rakyat Indonesia was merged. 
A bank that has a vision "To become a leading modern retail bank with a variety of financial services according to customer needs with the easiest reach for a more meaningful life. " Throughout 2011, PT Bank BRI Syariah has developed its branch network to increase its business activities. Bank BRI Syariah has 101 offices consisting of 8 main branch offices, 27 branch offices, 55 sub-branch offices and 11 cash offices. The number which exceeds the previous year's achievement is driven by the spirit of PT Bank BRI Syariah in providing the best service. With the above problems, BRI Syariah Bank is expected to survive with its advantages. Therefore it requires service quality, product quality and trust in order to achieve customer satisfaction.

\section{Literature Review}

\section{Quality of Service}

Quality means the level, quality, or level of good or bad something (Fajri and Senia 2008). While service is the provision of a performance or visible action from one party to another. In general, services are produced and consumed simultaneously, where the interaction between service providers and service recipients affects the results of these services. Therefore, service quality can be defined as the delivery of services that will exceed the level of customer interest (Rangkuti 2002). According to Tjiptono and Chandra (2007: 157), service quality is a measure of how well the level of service provided is in accordance with customer estimates. In principle, service quality focuses on efforts to meet the needs and wants as well as the accuracy of delivery to match customer expectations (Chandra Tjiptono 2007).

\section{Product Quality}

According to Sunyoto (2012: 69) a product is something that is offered and can satisfy consumer wants and needs. Products have an important meaning for the company because without them, the company will not be able to do anything from its business. Customers will buy products that they feel are suitable, therefore the company must adapt the product to the needs and desires of the customer for successful product marketing. A product is 
Effect of Service Quality, Product Quality, and...

something that can provide benefits both for daily needs or something that consumers want to have, and is usually used for consumption for physical and spiritual needs (Sunyoto 2012).

Product quality is the product's ability to carry out its functions including durability, reliability, ease of use and repair, and other properties (Machfoedz 2005). Such as phone banking, internet banking, debit cards and ATM cards (Marwini and Salam 2020). Product quality has a close relationship with customer satisfaction because product quality can be judged by the product's ability to create customer satisfaction values.

\section{Trust}

Trust is the truth about something that is believed, the belief in honesty, kindness, and so on to those who are trusted about something (Salim and Salim 1991). Customer trust is a perception that is owned by an individual, namely believing correctly what is conveyed by the party he trusts, can really keep his promises and can help in fulfilling needs and fulfilling the individual's expectations. In this case, customer trust is that if the quality of service provided by Islamic banks is good, the customer will believe that the funds are managed by Islamic banks.

Trust is the main key for the development or failure of an Islamic bank, meaning that without customer trust, Islamic banks will not be able to carry out their business activities (Hermansyah 2013). Trust indicates that Islamic banks can be trusted to remain committed to maintaining common interests and Islamic banks are perceived not only to pursue business interests (profit oriented), but also to consider customer needs and satisfaction (Krisyantono 2008).

\section{Customer Satisfaction}

For business people, customer satisfaction is seen as a dimension of market performance (Kotler 2008). The higher the level of customer satisfaction, it will bring high profits for the company, because customers will repurchase the products offered by the company. However, if the level of 
Heny Yuningrum, Muyassarah, Risma Dewi Astuti

satisfaction felt by the customer is small, then it is possible that the customer will move to another company's products. Customer satisfaction is the result felt by buyers who experience the performance of a company that matches their expectations. Customers will feel satisfied when their expectations are met and will feel very satisfied when they exceed their expectations. Satisfied customers will tend to be loyal to the products provided by the company and will benefit the company.

\section{Hypothesis}

H01 = There is no influence between service quality on customer satisfaction.

Ha1 = Service quality has a positive and significant effect on customer satisfaction.

H02 $=$ There is no influence between product quality on customer satisfaction.

Ha2 = Product quality has a positive and significant effect on customer satisfaction.

H03 = There is no influence between trust and customer satisfaction.

Ha3 = Trust has a positive and significant effect on customer satisfaction.

$\mathrm{H} 04=$ There is no influence between service quality, product quality, and trust on customer satisfaction.

Ha4 = Service quality, product quality, and trust have a positive and significant effect on customer satisfaction together.

\section{Methods}

\section{Types of Research}

The type of data used in this research is quantitative data. The type of quantitative data in this study was obtained through a questionnaire as a research instrument. 
Effect of Service Quality, Product Quality, and...

\section{Data Sources}

The data source in this research is primary data. Primary data in this study are data from direct observation and data from questionnaires, namely the results of respondents' answers to questionnaires submitted to customers at Bank Rakyat Indonesia Syariah Kendal Sub-Branch Office. Besides that, it also uses documentation techniques, documentation techniques are used to collect written data. The documentation in this study was obtained from bank documents, websites, and journals relating to the research title.

\section{Collecting Data Method}

The data collection method in this study was carried out using a questionnaire distribution technique. Researchers spread a list of questions to customers at Bank BRI Syariah KCP Kendal who were respondents in this study.

\section{Data Analysis Method}

This study uses validity and reliability tests, then classic assumption test, $\mathrm{t}$ test, $\mathrm{F}$ test, determination test and multiple linear regression equation test.

\section{Results and Discussion}

\section{Classic Assumption Test}

\section{Normality Test}

The normality test is used to see whether in the regression model the dependent variable (dependent) and the independent variable (independent) have a normal distribution or not. The data normality test in this study used statistical analysis. It can be seen from the table below that the value of the Kolmogorov-Smirnov test is 0.114 , which is greater than alpha 0.05 , so the data is normal. 
Heny Yuningrum, Muyassarah, Risma Dewi Astuti

Table 1. One-Sample Kolmogorov-Smirnov Test

One-Sample Kolmogorov-Smirnov Test

\begin{tabular}{|ll|r|}
\hline & & $\begin{array}{r}\text { Unstandardized } \\
\text { Residual }\end{array}$ \\
\hline $\mathrm{N}$ & 100 \\
Normal Parametersa, b & Mean & .0000000 \\
& Std. Deviation & 1.32578915 \\
Most Extreme Differences Absolute & .080 \\
& Positive & .074 \\
& Negative & -.080 \\
Statistical Test & & .080 \\
Asymp. Sig. (2-tailed) & & $.114 \mathrm{c}$ \\
\hline
\end{tabular}

a. Test distribution is Normal.

b. Calculated from data.

c. Lilliefors Significance Correction.

Table 2. Heteroskdasticity Test Results

Coefficientsa

\begin{tabular}{|c|c|c|c|c|c|}
\hline \multirow[b]{2}{*}{ Model } & \multicolumn{2}{|c|}{$\begin{array}{c}\text { Unstandardized } \\
\text { Coefficients }\end{array}$} & \multirow{2}{*}{ 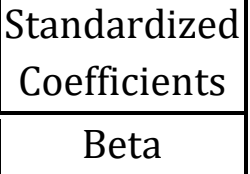 } & \multirow[b]{2}{*}{$\mathrm{T}$} & \multirow[b]{2}{*}{ Sig. } \\
\hline & B & Std. Error & & & \\
\hline 1 (Constant) & .178 & 1,740 & & .102 & .919 \\
\hline $\begin{array}{l}\text { Quality of } \\
\text { Service }\end{array}$ & .004 & .044 & .009 & .086 & .932 \\
\hline Product quality & .035 & .080 & .045 & .441 & .660 \\
\hline Trust & .023 & .070 & .033 & .325 & .746 \\
\hline
\end{tabular}

a. Dependent Variable: ABS_RES 
Effect of Service Quality, Product Quality, and...

\section{Heteroscedasticity Test}

The heteroscedasticity test is a test tool that aims to test whether in the regression model there is an inequality of variance from the residuals of one observation to another. The heteroscedasticity test in this study used the Glejser test. Based on the table above, it can be seen that the value (Sig). service quality of 0.932 , value (Sig). product quality of 0.660 , and value (Sig). confidence is 0.746 . To see whether heteroscedasticity occurs or not, then the value (Sig). should be compared with 0.05 . So it can be concluded that heteroscedasticity does not occur because of value (Sig). service quality, product quality, and trust variables were greater than 0.05 .

\section{Multicollinearity Test}

The multicollinearity test aims to see whether or not there is a high correlation between the independent variables in a multiple linear regression model. Based on table 4.9 it can be seen that multicollinearity does not occur, because the Variance Inflation Factor (VIF) value does not exceed 10.00.

Table 3. Multicollinearity Test Results

Coefficientsa

\begin{tabular}{|c|c|c|c|c|c|c|c|}
\hline \multirow[b]{2}{*}{ Model } & \multicolumn{2}{|c|}{$\begin{array}{c}\text { Unstandardized } \\
\text { Coefficients }\end{array}$} & \multirow{2}{*}{$\begin{array}{c}\text { Standardized } \\
\text { Coefficients } \\
\text { Beta }\end{array}$} & \multirow[b]{2}{*}{$\mathrm{T}$} & \multirow[b]{2}{*}{ Sig. } & \multicolumn{2}{|c|}{$\begin{array}{c}\text { Collinearity } \\
\text { Statistics }\end{array}$} \\
\hline & B & Std. Error & & & & Tolerance & VIF \\
\hline 1 (Constant) & -108 & 2,630 & & -.041 & .967 & & \\
\hline $\begin{array}{l}\text { Quality of } \\
\text { Service }\end{array}$ & .139 & .066 & .192 & 2,100 & .038 & .987 & 1,013 \\
\hline $\begin{array}{l}\text { Product } \\
\text { quality }\end{array}$ & .249 & .122 & .187 & 2,045 & .044 & .991 & 1,009 \\
\hline Trust & .463 & .107 & .397 & 4,343 & .000 & .991 & 1,009 \\
\hline
\end{tabular}

a. Dependent Variable: Customer Satisfaction 
Heny Yuningrum, Muyassarah, Risma Dewi Astuti

\section{Multiple Linear Regression Test}

Multiple linear regression analysis is an analysis used to determine the effect of several $\mathrm{X}$ variables on one dependent variable $\mathrm{Y}$. The following are the results of multiple linear regression tests:

AL-ARBAH | 150 Table 4. Multiple Linear Regression Test Results

\begin{tabular}{|c|c|c|c|c|c|}
\hline \multirow[b]{2}{*}{ Model } & \multicolumn{2}{|c|}{$\begin{array}{l}\text { Unstandardized } \\
\text { Coefficients }\end{array}$} & \multirow{2}{*}{$\begin{array}{c}\text { Standardized } \\
\text { Coefficients } \\
\text { Beta }\end{array}$} & \multirow[b]{2}{*}{$\mathbf{T}$} & \multirow[b]{2}{*}{ Sig. } \\
\hline & B & Std. Error & & & \\
\hline (Constant) & -108 & 2,630 & & -.041 & .967 \\
\hline $\begin{array}{l}\text { Quality of } \\
\text { Service }\end{array}$ & .139 & .066 & .192 & 2,100 & .038 \\
\hline Product Quality & .249 & .122 & .187 & 2,045 & .044 \\
\hline Trust & .463 & .107 & .397 & 4,343 & .000 \\
\hline
\end{tabular}

a. Dependent Variable: Customer Satisfaction

Based on the table above, the multiple linear regression equation can be obtained as follows:

$$
\begin{aligned}
& \mathrm{Y}=a+\mathrm{b} 1 \mathrm{X} 1+\mathrm{b} 2 \mathrm{X} 2+\mathrm{b} 3 \mathrm{X} 3+\mathrm{e} \\
& \mathrm{Y}=-0.108+0.139 \mathrm{X} 1+0.249 \mathrm{X} 2+0.463 \mathrm{X} 3+\mathrm{e}
\end{aligned}
$$

\section{Discussion}

\section{Service Quality (X1) to Customer Satisfaction (Y)}

The regression coefficient value of the $\mathrm{X} 1$ variable is positive, which is equal to 0.139 , meaning that if the service quality variable has increased by 1 , the volume of customer satisfaction will increase by 0.139 .

\section{Product Quality (X2) to Customer Satisfaction (Y)}

The regression coefficient value of the X2 variable is 0.249 , meaning that if the product quality variable has increased by 1 , it will cause an increase in the value of the Customer Satisfaction variable (Y) of 0.249. 
Effect of Service Quality, Product Quality, and...

\section{Trust (X3) on Customer Satisfaction (Y)}

The regression coefficient value of the $\mathrm{X} 3$ variable is positive, which is equal to 0.463 , meaning that if the service quality variable has increased by 1 , the volume of customer satisfaction will increase by 0.463 .

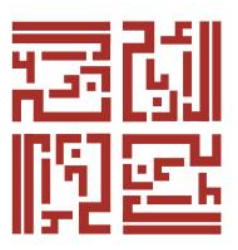

\section{T Test}

The $\mathrm{T}$ test was conducted to determine whether individually (partially) the independent variables (Service Quality, Product Quality, and Trust) significantly influence the dependent variable (Customer Satisfaction) or not.

Table 5. Coefficientsa

\begin{tabular}{lccccc}
\hline & Unstandardized Coefficients & \multicolumn{2}{c}{$\begin{array}{c}\text { Standardized } \\
\text { Coefficients }\end{array}$} & & \\
\cline { 2 - 4 } Model & $\mathbf{B}$ & Std. Error & Beta & T & Sig. \\
\hline 1 (Constant) & -108 & 2,630 & & -.041 & .967 \\
$\begin{array}{l}\text { Quality of } \\
\text { Service }\end{array}$ & .139 & .066 & .192 & 2,100 & .038 \\
$\begin{array}{l}\text { Product } \\
\text { Quality }\end{array}$ & .249 & .122 & .187 & 2,045 & .044 \\
Trust & .463 & .107 & .397 & 4,343 & .000 \\
\hline
\end{tabular}

a. Dependent Variable: Customer Satisfaction

Based on the table above in detail, the following tests are produced:

1. The service quality variable has a significance value of 0.038 , where $0.038<0.05$. This means that Ha is accepted and HO is rejected. Meanwhile, if viewed by comparing between $t$ count and $t$ table, the variable service quality has $t$ count of 2,100 with $t$ table of 1.984 meaning $t$ count $>t$ table which means Ha accepted. So it can be concluded that the variable service quality has an effect on customer satisfaction and Ha is accepted.

2. The product quality variable has a significance value of 0.044 where $0.044<0.05$. This means that Ha is accepted and HO is rejected. Meanwhile, when viewed by comparing between $t$ count and $t$ table, 
the variable product quality has t count of 2.045 with $t$ table of 1.984 meaning $t$ count $>t$ table which means Ha accepted. So it can be concluded that the variable product quality affects customer satisfaction and Ha is accepted.

3. The trust variable has a significance value of 0.000 , where 0.000 $<0.05$. This means that $\mathrm{Ha}$ is accepted and $\mathrm{HO}$ is rejected. Meanwhile, when viewed by comparing between $t$ count and $t$ table, the trust variable has $t$ count of 4.343 with $t$ table of 1.984 meaning $t$ count $>t$ table which means Ha is accepted. So it can be concluded that the variable trust affects customer satisfaction and Ha is accepted.

\section{F test}

The F test is used to determine whether together (simultaneously) the coefficient of the independent variables has an influence or not on the dependent variable.

\section{Table 6. ANOVAa}

\begin{tabular}{lccccc}
\hline Model & Sum of Squares & Df & Mean Square & F & Sig. \\
\hline 1 Regression & 44,826 & 3 & 14,942 & 8,243 & $.000 \mathrm{~b}$ \\
Residual & 174,014 & 96 & 1,813 & & \\
Total & 218,840 & 99 & & & \\
\hline
\end{tabular}

a. Dependent Variable: Customer Satisfaction

b. Predictors: (Constant), Trustworthiness, Product Quality, Service Quality F test results obtained Fcount of 8,243 with a significance level of 0.000 $<0.05$. And from the table it shows for F count of 8,243 and $F$ table of 2,699, which means 8,243>2,699. So it can be concluded that $\mathrm{H} 0$ is rejected and $\mathrm{Ha}$ is accepted, then the hypothesis which states that the variables Service Quality, Product Quality, and Trust together have an effect on Customer Satisfaction. 
Effect of Service Quality, Product Quality, and...

Coefficient of Determination (R2)

Table 7. Determination Coefficient Results (R2)

\begin{tabular}{ccccc}
\hline Model & $\mathbf{R}$ & $\mathbf{R}$ Square & Adjusted R Square & Std. Error of the Estimate \\
\hline $\mathbf{1}$ & $.453 \mathrm{a}$ & .245 & .180 & 1,346 \\
\hline
\end{tabular}

a. Predictors: (Constant), Trustworthiness, Product Quality, Service Quality

b. Dependent Variable: Customer Satisfaction

Based on the table above, it can be seen that R square (R2) is 0.180 or $18 \%$ which indicates that there is an influence of service quality, product quality, and trust variables on customer satisfaction by $18 \%$ and the remaining $82 \%$ is influenced by other variables not included in the study this.

\section{Conclusion}

Service quality variables have a positive and significant effect on customer satisfaction. This is evidenced by the service quality variable which has a $t$ count of 2.100 with a $t$ table of 1.984, which means $t>t$ table, and a significance value of 0.038 where this value is $<0.05$ and is positive at 0.139 . Product quality variables have a positive and significant effect on customer satisfaction. This is evidenced by the variable product quality which has a $t$ count of 2.045 with a $t$ table of 1.984 , meaning $t>t$ table, and a significance value of 0.044 where this value is $<0.05$ and is positive at 0.249 . Trust variable has a positive and significant effect on customer satisfaction. This is evidenced by the trust variable has a t count of 4.343 with a t table of 1 . 
Heny Yuningrum, Muyassarah, Risma Dewi Astuti

\section{References}

Annual Report Bank BRI Syariah Tahun 2011 diakses pada 24 Desember 2019 pukul 09:45 WIB

Awwallin, Dhika Putri. 2015. "Perbankan Syariah Indonesia Dalam Menghadapi Persaingan Masyarakat Ekonomi Asean (MEA) 2015." Jurnal Akuntansi AKUNESA 3 (2). https://jurnalmahasiswa.unesa.ac.id/index.php/jurnalakuntansi/article/view/13340

Chandra Tjiptono. 2007. Service, Quality \& Satisfaction. Yogyakarta: Andi Offset

Fajri, Em Zul, and Ratu Aprillia Senia. 2008. Kamus Lengkap Bahasa Indonesia. Semarang: Difapublisher

Hermansyah. 2013. Hukum Perbankan Nasional Indonesia. Jakarta: Kencana Prenada Media Group

Hermanto, Hermanto. 2013. "Pengaruh Kualitas Pelayanan SDM Bank Syariah Terhadap Kepuasan Nasabah: Studi Pada BPRS Berkah Ramadhan." $\quad$ ETIKONOMI 12 https://doi.org/10.15408/etk.v12i1.1907

Kotler, Philip. 2008. Manajemen Pemasaran. Jakarta: Indeks Kelompok Gramedia

Krisyantono, Rachmad. 2008. Public Relations Writing. Jakarta: Kencana

Machfoedz. 2005. Pengantaran Pemasaran Modern. Yogyakarta: Akademi Manajemen Perusahaan YKPN

Marwini, and Annisa Nur Salam. 2020. "E-Money Based Boarding School Cooperative Development Model (Kopontren) As An Sharia Economic Acceleration Effort In Indonesia | Marwini | AL-ARBAH: Journal of Islamic Finance and Banking." AL-ARBAH: Journal of Islamic Finance and

Banking 2 https://journal.walisongo.ac.id/index.php/arbah/article/view/5496

Mastura, Zainatun. 2018. "Pengaruh Kualitas Pelayanan Dan Kepercayaan Nasabah Terhadap Kepuasan Nasabah (Studi Pada PT. Bank Aceh Syariah KPO Banda Aceh)," October, 141. http://library.ar-raniry.ac.id/

Muyassarah, Muyassarah. 2019. "Analisis SWOT Pada Strategi Pemasaran Produk Simpanan Kurban Di KSPPS BMT NU Sejahtera Cabang Jepara." 
Effect of Service Quality, Product Quality, and...

SERAMBI: Jurnal Ekonomi Manajemen Dan Bisnis Islam 1 (3): 71. https://doi.org/10.36407/serambi.v1i3.72

Rangkuti. 2002. Measuring Customer Satisfaction. Jakarta: Gramedia Pustaka Utama

Salim, Peter, and Yeni Salim. 1991. Kamus Bahasa Indonesia Kontemporer.

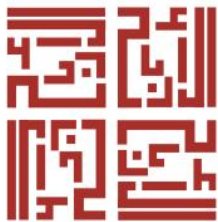
Jakarta: Graha Persada.

Setiawan, Heri, Maria Magdalena Minarsih, and Azis Fathoni. 2016. "Pengaruh Kualitas Produk, Kualitas Pelayanan Dan Kepercayaan Terhadap Kepuasan Nasabah Dan Loyalitas Nasabah Dengan Kepuasan Sebagai Variabel Intervening (Studi Kasus Pada Nasabah Koperasi Rejo Agung Sukses Cabang Ngaliyan)." Journal of Management 2 (2). https://jurnal.unpand.ac.id/index.php/MS/article/view/492

Sunyoto, Danang. 2012. Dasar-Dasar Manajemen Pemasaran. Yogyakarta: CAPS

Tjiptono, Fandy. 2014. Pemasaran Jasa-Prinsip, Penerapan, Dan Penelitian, Yogyakarta. Yogyakarta: CV. Andi Offset

Yusrina. 2013. "Peranan Citra Perusahaan Terhadap Kepercayaan Nasabah Bank BRI Cabang Banda Aceh - PDF Free Download.” Jurnal Ekonomi Manajemen Dan Bisnis 1 (2): 203-13. https://docplayer.info/42719082-Peranan-citra-perusahaanterhadap-kepercayaan-nasabah-bank-bri-cabang-banda-aceh.html

Brisyariah.co.id diakses pada 3 Juli 2010 pukul 20.06 WIB

Roadmap perbankan syariah Indonesia 2015-2019. Diakses pada 15 Desember 2019 pukul 13:23 
Heny Yuningrum, Muyassarah, Risma Dewi Astuti

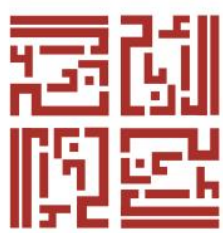

AL-ARBAH | 156 